\title{
Efficient thieno[3,2-a]carbazole-based organic dyes for dye-sensitized solar cells
}

Hua Jiang, ${ }^{\mathrm{a}, \mathrm{b}}$ Kazuaki Oniwa, ${ }^{\mathrm{b}}$ Ashraful Islam, ${ }^{\mathrm{c}, *}$ Jian Zhao, ${ }^{\mathrm{b}}$ Liyuan Han, ${ }^{\mathrm{c}}$ Ying-Ji Sun, ${ }^{\mathrm{a}}$ Ming Bao, ${ }^{\mathrm{a}}$ Naoki Asao, ${ }^{\mathrm{b}}$ Yoshinori Yamamoto, ${ }^{\mathrm{a}, \mathrm{b}}$ Tienan Jin ${ }^{\mathrm{b}, *}$

${ }^{a}$ State Key Laboratory of Fine Chemicals and School of Chemistry, Dalian University of Technology, Dalian 116023, China

${ }^{\mathrm{b}}$ WPI-Advanced Institute for Materials Research (WPI-AIMR), Tohoku University, Sendai 980-8577, Japan. Corresponding author: e-mail: tjin@m.tohoku.ac.jp (T.J.); yoshi@m.tohoku.ac.jp (Y.Y.); Tel.: 81-22-217-6177; fax: +81-22-217-5979

${ }^{\mathrm{c}}$ Photovoltaic Materials Unit, National Institute for Materials Science, Tsukuba 305-0047, Japan. ISLAM.Ashraful@nims.go.jp (A.I.)

Dedicated to Professor Emeritus Jiro Tsuji for his outstanding contribution to chemistry of palladiumcatalyzed reactions

\begin{abstract}
A new series of donor- $\pi$-acceptor organic dyes based on thieno[3,2- $a]$ carbazole as a new donor moiety, designated as JH-dyes, has been synthesized for dye-sensitized solar cells (DSCs). The photophysical properties and DSC performances of JH-dyes have been characterized. Among the three JH-dyes, a high power conversion efficiency $(\eta)$ of $8.04 \%$ with a short-circuit current $\left(J_{\mathrm{sc}}\right)$ of $14.08 \mathrm{~mA} \mathrm{~cm}$ and an open-circuit voltage $\left(V_{\mathrm{oc}}\right)$ of $0.78 \mathrm{~V}$ has been achieved for DSC based on JH03 bearing hexyl chains on the terthiophene $\pi$-linker. The electrochemical impedance spectra (EIS) and intensity-modulated photovoltage spectroscopy (IMVS) of JH-cells were measured to understand the effect of molecular structure on charge transfer process and electron life time.
\end{abstract}

Key words: thieno[3,2-a]carbazole, donor- $\pi$-acceptor, dye-sensitized solar cell, molecular planarity, charge transfer

\section{Introduction}

Dye-sensitized solar cells (DSCs) based on metal complex sensitizers and metal-free organic dyes have been considered as a promising next generation photovoltaic technology for solar energy transformation owing to their low cost, high efficiency, light weight, and long term stability. ${ }^{1}$ Among the photosensitizers, the metal-free organic dyes composed of a donor- $\pi$-linker-acceptor (D- $\pi$-A) structure, have been widely employed in DSCs as panchromatic sensitizers owing to their wide absorption, high molar extinction coefficients, flexible molecular engineering, efficient charge transfer, and the elimination of often costly transition metal ions. ${ }^{2}$ However, to date, the efficiency of about $10.3 \%$ for metal-free $\mathrm{DSCs}^{3}$ has been achieved by the rational molecular design and device optimization, the efficiencies are still lower than that of the metal-based DSCs (more than $12.3 \%$ efficiency). ${ }^{4}$ In an 
attempt to improve the efficiency a number of D- $\pi$-A dyes based on various electron-donating groups, such as coumarin, ${ }^{5 \mathrm{a}}$ perylene,${ }^{5 \mathrm{~b}}$ triarylamine,${ }^{5 \mathrm{c}}$ carbazole,${ }^{5 \mathrm{~d}}$ indoline, ${ }^{5 \mathrm{e}}$ and others ${ }^{2}$ have been developed to fine-tune the optical and electrochemical properties of organic dyes for high performance DSCs.

Key to achieving high efficiency DSCs is the increase of both short-circuit current $\left(J_{\mathrm{sc}}\right)$ and opencircuit voltage $\left(V_{\mathrm{oc}}\right) .{ }^{5 \mathrm{~d}, 6}$ Design of organic D- $\pi$-A dyes having long and planar $\pi$-conjugated systems with bulky substituents on the dye backbones is one of the effective ways to obtain both high $V_{\text {oc }}$ and $J_{\text {sc }}$ by expanding the absorption spectra and intramolecular charge transfer (ICT) while suppressing dye aggregation and charge recombination. ${ }^{5 \mathrm{~d}, 7}$ With these considerations in mind we have recently synthesized a new sires of thieno[2,3-a]carbazole dyes, designated K-dyes (Fig. 1), which showed a high planarity due to the small steric hindrance between the thienyl moiety of thieno[2,3- $a$ ]carbazole and the $\pi$-linkage, resulted in the efficient $\pi$-conjugation and hence enhanced ICT. ${ }^{8}$ Moreover, the introduction of bulkyl substituents of hexyl chains in the $\pi$-linkage of K-5 dye increased the efficiency up to $7 \%$ under the identical device conditions owing to the prolonged life time. ${ }^{8 \mathrm{~b}}$ In our continuous efforts to improve the DSC performance and study the relationship between the molecular structure and the device performance, ${ }^{8,9}$ we designed a new series of thieno[3,2-a]carbazole dyes, designated JH01-03 (see Scheme 1) to obtain higher photon-to-current efficiencies based on the performances of K-dyes. Herein, we report the synthesis, photophysical properties, and characterization of JH01-03 dyes (Scheme 1). JH01 and JH02 dyes with bithophene as a $\pi$-linkage in the D- $\pi$-A and $2 \mathrm{D}-\pi$-A structures exhibited a high molecular planarity and enhanced ICT absorption, resulted in the power conversion efficiencies of $5.96 \%$ and $7.25 \%$, respectively. The JH03 dye having hexyl chains on the terthiophene $\pi$-linker showed a twisted backbone, which afforded a high efficiency of $8.04 \%$ due to the increased $J_{\text {sc }}$ and $V_{\text {oc }}$, which is higher than the K-5 dye. ${ }^{8 b}$
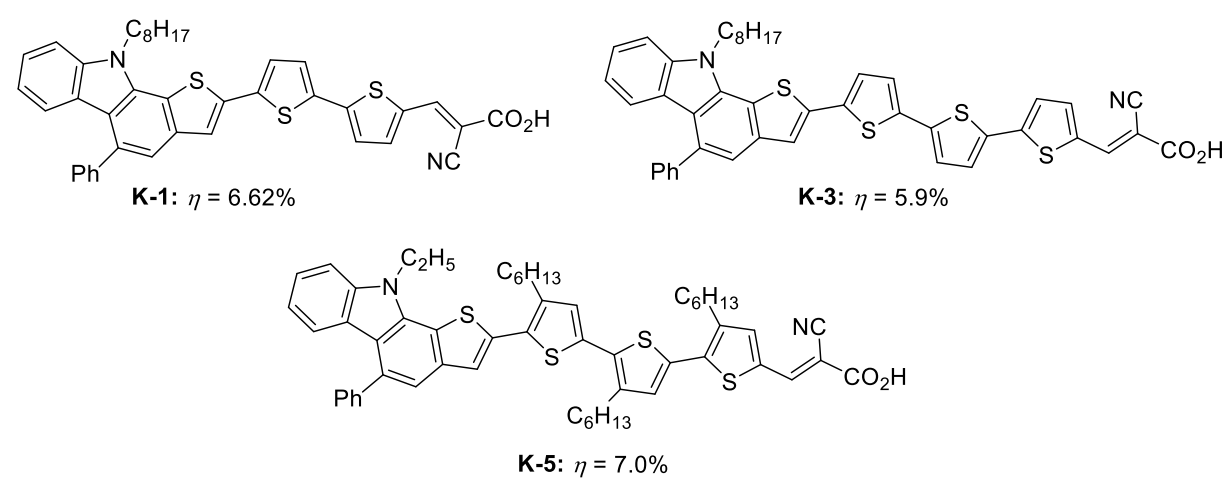

Fig. 1. Our previous K-dyes based on thieno[2,3-a]carbazole as an electron-donating group and their DSC performances.

\section{Results and discussion}

The detailed synthetic routes to JH-dyes are shown in Scheme 1. The thieno[3,2-a]carbazole units 1ac were synthesized by our gold-catalyzed cascade cyclization of aniline-substituted arenyl diynes. ${ }^{10}$ The thieno[3,2-a]carbazole $\mathbf{1 b}$ having a bromo-substituent at the 5-position of the phenyl ring was further converted to the $N, N$-diphenylamine-substituted 1b' through the Buchwald-Hartwig amination 
reaction. ${ }^{11}$ After lithiation and borylation of the active $\alpha$-position of the thienyl moiety in $\mathbf{1}$, the resulting boronates $\mathbf{2 a}$ and $\mathbf{2 b}$ reacted with the bithiophene $\pi$-linker $\mathbf{4}$ through the Suzuki-Miyaura coupling reaction to give the corresponding aldehydes $\mathbf{3 a}$ and $\mathbf{3 b}$ in $81 \%$ and $85 \%$ yields, respectively. Under the same conditions, the reaction of the boronate $\mathbf{2 c}$ with the hexyl-substituted terthiophene $\mathbf{5}$ afforded the corresponding aldehyde $\mathbf{3 c}$ in $80 \%$ yield. The resulting aldehydes 3a-c reacted with cyanoacetic acid under Knoevenagel condensation conditions ${ }^{12}$ to produce the desired organic dyes, JH01, JH02, and JH03 in good to high yields. The obtained three dyes were washed with EtOH and characterized by ${ }^{1} \mathrm{H}$ NMR, ${ }^{13} \mathrm{C}$ NMR and HRMS. It is noted that in this work, we designed JH01 and JH02 dyes on the basis of our previous results with dye K-3 which showed that a terthiophene $\pi$-linker decreased the DSC performance compared to that of K-1 having a bithophene $\pi$-linker due to the strong intermolecular $\pi-\pi$ interaction.

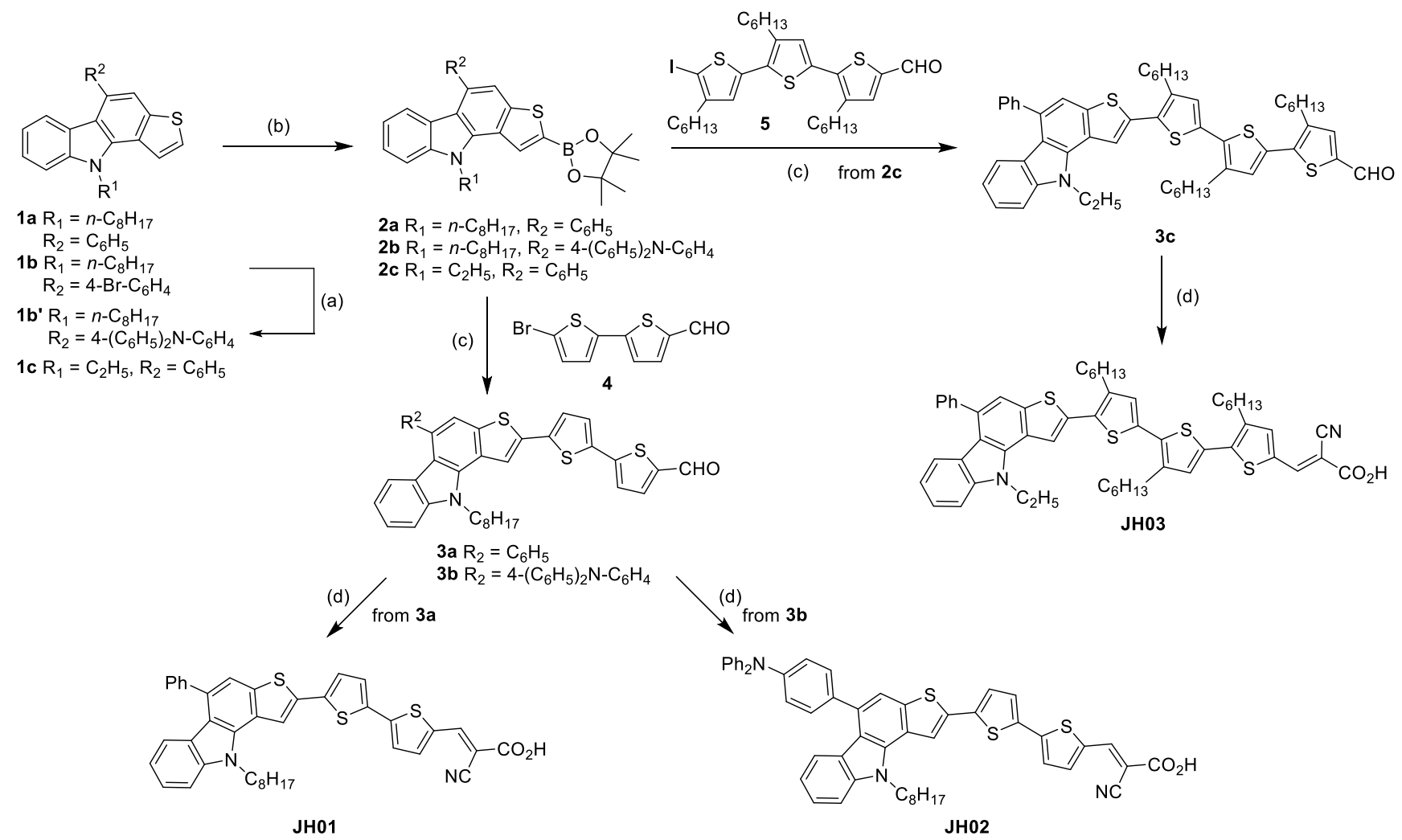

Scheme 1. Synthesis of JH-dyes. (a) $\mathrm{Ph}_{2} \mathrm{NH}, \mathrm{Pd}_{2}(\mathrm{dba})_{3}(1 \mathrm{~mol} \%),(t-\mathrm{Bu})_{3} \mathrm{P}(4 \mathrm{~mol} \%), \mathrm{NaO}{ }^{t} \mathrm{Bu}$, toluene, $100{ }^{\circ} \mathrm{C}, 75 \%$. (b) $n$-BuLi, THF, $-78{ }^{\circ} \mathrm{C}$ for $30 \mathrm{~min}$ followed by 2 -isopropoxy-4,4,5,5-tetramethyl-1,3,2dioxaborolane, THF, $-78{ }^{\circ} \mathrm{C}$ to rt for 2 h. (c) 4 or $\mathbf{5}, \mathrm{Pd}\left(\mathrm{PPh}_{3}\right)_{4}(10 \mathrm{~mol} \%), \mathrm{K}_{2} \mathrm{CO}_{3}, \mathrm{DME} / \mathrm{H}_{2} \mathrm{O}(10 / 1)$, reflux; 3a: $81 \%$, 3b: 85\%, 3c: 80\%. (d) $\mathrm{CNCH}_{2} \mathrm{COOH}, \mathrm{NH}_{4} \mathrm{OAc} / \mathrm{HOAc}, 110{ }^{\circ} \mathrm{C}$; JH01: 66\%, JH02: 60\%, JH03: $89 \%$.

The photophysical properties of JH-dyes measured in chloroform and on the $\mathrm{TiO}_{2}$ film, are shown depicted in Fig. 2 and summarized in Table 1. All the three JH-dyes show broad and strong absorption bands in the visible region due to donor-acceptor intramolecular charge transfer and $\pi-\pi^{*}$ excitation, 
which are similar to that of K-dye. ${ }^{8}$ In comparison with the simple D- $\pi$-A structure of JH01 dye, JH02 dye exhibits a red-shifted ICT absorption band and an enhanced absorption coefficient $(\varepsilon)$ in the range of 400-600 nm, presumably due to the additional electron-donating group of diphenylamine. On the other hand, JH03 dye having hexyl chains on the terthiophene $\pi$-bridge shows a blue-shifted ICT absorption and a lower $\varepsilon$ compared with JH01 and JH02 dyes. These properties imply that the JH01 and JH02 dyes combining the thieno[3,2- $a$ ]carbazole with the bithiophene $\pi$-bridge possess a higher planarity of the $\pi$-conjugated backbone compared with the $\mathbf{J H 0 3}$ dye having bulky hexyl chains on the $\pi$-linkage, which are favorable for the efficient ICT transition from donor to acceptor and the $\varepsilon$ values. It is also noted that the absorption onsets of the three dyes are almost the same, regardless of the introduction of diphenylamine or a longer terthiophene $\pi$-bridge. As plotted in Figure $2 b$, all the three dyes show broad absorption spectra on the transparent $\mathrm{TiO}_{2}$ film with the wavelengths up to $700 \mathrm{~nm}$, which are desirable for harvesting the solar spectrum and generation of a higher photocurrent. The absorption maxima of the three $\mathrm{JH}$-dyes on the $\mathrm{TiO}_{2}$ film $(539 \sim 558 \mathrm{~nm})$ are largely red-shifted compared with those in solution, which is in contrast with the blue-shifted absorption of K-1 dye (442 nm). ${ }^{8 \mathrm{a}}$ The large red-shifts suggest the existence of the intermolecular $\pi-\pi$ interaction of $\mathrm{JH}$-dyes on the $\mathrm{TiO}_{2}$ film. Among the $\mathrm{JH}$-dyes, JH03 dye shows the most red-shifted absorption, which is different with that in solution.
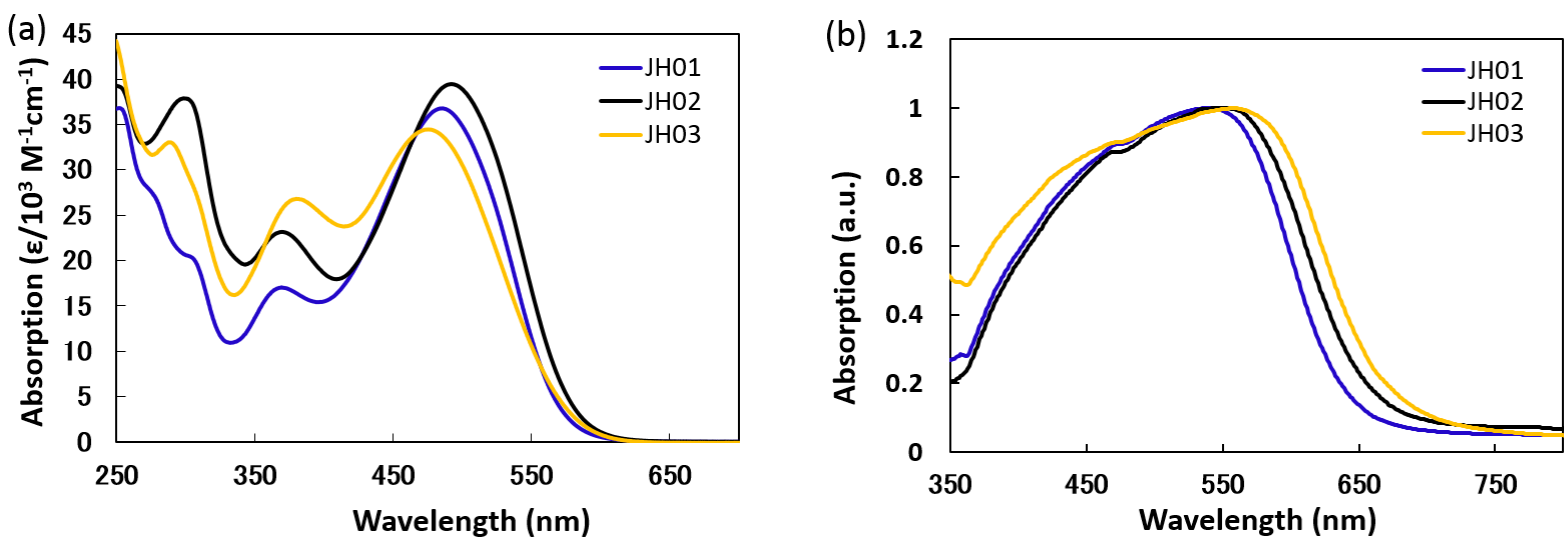

Fig. 2. UV-vis absorption spectra of JH-dyes, (a) in chloroform solution, (b) on $\mathrm{TiO}_{2}$ nanoparticles.

The electrochemical properties of $\mathrm{JH}$-dyes were investigated by cyclic voltammetry $(\mathrm{CV})$ in $\mathrm{CH}_{2} \mathrm{Cl}_{2}$ using $\mathrm{TBAPF}_{6}$ as a supporting electrolyte (Table 1). The highest occupied molecular orbital (HOMO) energy levels were measured to be $-5.38 \mathrm{eV}$ for JH01, $-5.24 \mathrm{eV}$ for $\mathbf{J H 0 2}$, and $-5.27 \mathrm{eV}$ for JH03, respectively (Fig. S2). The ionization potentials (IP) of the JH-dyes bound to the nanocrystalline $\mathrm{TiO}_{2}$ film, which correspond to ground-state oxidation potentials $\left(S^{+/ 0}\right)$, were also measured using the photoemission yield spectrometer (Riken Keiki, AC-3E). The IP values are in accordance with the HOMOs obtained from CV measurements (Fig. S1), which are lower than the redox potential of $\mathrm{I}^{-} / \mathrm{I}_{3}^{-}{ }^{-}-$ $5.2 \mathrm{eV}),{ }^{13}$ ensuring the regeneration of the oxidized dyes by the reaction with $\mathrm{I}^{-}$. The HOMOs of JH02 and JH03 are positively shifted compared to that of JH01, due to the electron-donating properties of diphenylamine in $\mathbf{J H 0 2}$ and hexyl chains on terthiophene in $\mathbf{J H 0 3}$, which are favorable for the ICT from donor to acceptor units. Optical energy gaps $\left(\mathrm{E}_{0-0}\right)$ of the $\mathrm{JH}$-dyes, calculated from the onsets of the 
absorption in solution, are in the range of 2.00 2.03 eV. The lowest unoccupied molecular orbital (LUMO) energy levels are thus calculated to be $-3.35 \mathrm{eV}$ for $\mathbf{J H 0 1},-3.24 \mathrm{eV}$ for JH02, and $-3.26 \mathrm{eV}$ for JH03, respectively, which are sufficiently higher than the conduction band edge of $\mathrm{TiO}_{2}(-4.2 \mathrm{eV}){ }^{1 \mathrm{c}}$ ensuring the electron injection from the excited dyes into the conduction band of $\mathrm{TiO}_{2}$.

Table 1. Absorption and electrochemical properties of JH-dyes

\begin{tabular}{|c|c|c|c|c|c|c|}
\hline Dye & $\begin{array}{c}\lambda_{\max }(\mathrm{nm}) \\
\left(\varepsilon / \mathrm{M}^{-1} \mathrm{~cm}^{-1}\right)^{\mathrm{a}}\end{array}$ & $\begin{array}{l}\lambda_{\max }(\mathrm{nm}) \\
\text { on } \mathrm{TiO}_{2}{ }^{\mathrm{b}}\end{array}$ & $\operatorname{IP}(e V)^{c}$ & $\mathrm{E}_{0-0}(\mathrm{eV})^{\mathrm{d}}$ & $\operatorname{HOMO}(\mathrm{eV})^{\mathrm{e}}$ & LUMO $(\mathrm{eV})^{\mathrm{f}}$ \\
\hline JH01 & $486(36790)$ & 539 & -5.46 & 2.03 & -5.38 & -3.35 \\
\hline JH02 & 492 (39476) & 551 & -5.34 & 2.00 & -5.24 & -3.24 \\
\hline JH03 & $476(34420)$ & 558 & -5.30 & 2.01 & -5.27 & -3.26 \\
\hline
\end{tabular}

${ }^{a}$ Absorption maxima, measured in chloroform at room temperature.

${ }^{\mathrm{b}}$ Absorption measured on a transparent $4 \mu \mathrm{m} \mathrm{TiO} 2$ film.

${ }^{c}$ Ionization potential (IP) of absorbed dyes on the nanocrystalline $\mathrm{TiO}_{2}$ film was determined by using the photoemission yield spectrometer (Riken Keiki, AC-3E).

${ }^{\mathrm{d}}$ Optical bandgap $\left(\mathrm{E}_{0-0}\right)$ was determined from the on-set of the absorption in chloroform.

${ }^{\mathrm{e}}$ The HOMO energy levels were calculated from the onset of the first oxidation potentials $\left(\mathrm{E}_{\text {ox }}^{1}\right)$.

${ }^{f}$ The LUMO energy levels were calculated from the expression of LUMO $=\mathrm{HOMO}+\mathrm{E}_{0-0}$.

The optimization of the ground-state geometries and the calculation of the molecular frontier orbitals of JH-dyes were also performed using the hybrid DFT energy functional B3LYP/6-31G++** (Fig. S3). The HOMOs of JH-dyes mainly delocalized over the thieno[3,2-a]carbazole donor and the diphenylamine moiety (in the case of JH02) as well as the oligothiophene $\pi$-bridge, which indicate the electron-donating property of the thieno[3,2-a]carbazole moiety. On the other hand, the LUMOs of JHdyes are mainly delocalized on the electron-accepting cyanoacrylic acid moiety and the adjacent $\pi$ bridge. The HOMO and LUMO distributions are appropriate for efficient charge transfer and electron injection into the $\mathrm{TiO}_{2}$ conduction band. Small dihedral angles of $1^{\circ}$ and $6^{\circ}$ between the thienocarbazole moiety and the adjacent thiophene ring have been calculated for JH01 and JH02, indicating the good planarity and rigidity of these two dyes. In contrast, the dihedral angle of $\mathbf{J H 0 3}$ (calculation was performed using the $n$-propyl group instead of the $n$-hexyl group) between thienocarbazole and the neighboring hexylthiophene was calculated to be about $36^{\circ}$, because of the steric repulsion between the large sulphur atom and the hexyl chain, which is similar to the result obtained from the K-5 dye. ${ }^{8 \mathrm{~b}}$

The photovoltaic characteristics of DSCs based on JH-dyes were measured under AM 1.5G irradiation at a light intensity of $100 \mathrm{~mW} \cdot \mathrm{cm}^{-2}$. The incident photon-to-current conversion efficiency (IPCE) spectra for DSCs based on the JH-dyes, plotted in Figure 3a, are consistent with the absorption spectra observed for $\mathrm{TiO}_{2}$ films. The IPCE spectra of the three dyes broaden toward the red region in the order of $\mathbf{J H 0 3}>$ JH02 > JH01, and the onsets of the IPCE spectra of JH02 and JH03 cells reach to about $750 \mathrm{~nm}$. The maximum quantum efficiency value of $\mathbf{J H 0 3}$ in the plateau region approaches to $86 \%$, which is higher than that of K-5 dye $(75 \%)^{8 b}$ having a thieno[2,3-a]carbazole donor moiety. The JH02 dye having an 
additional diphenylamine donor shows a slightly higher maximum IPCE than that of the JH01 dye in the plateau region. Consequently, a better electron injection efficiency are expected for the JH02 and JH03 cells.
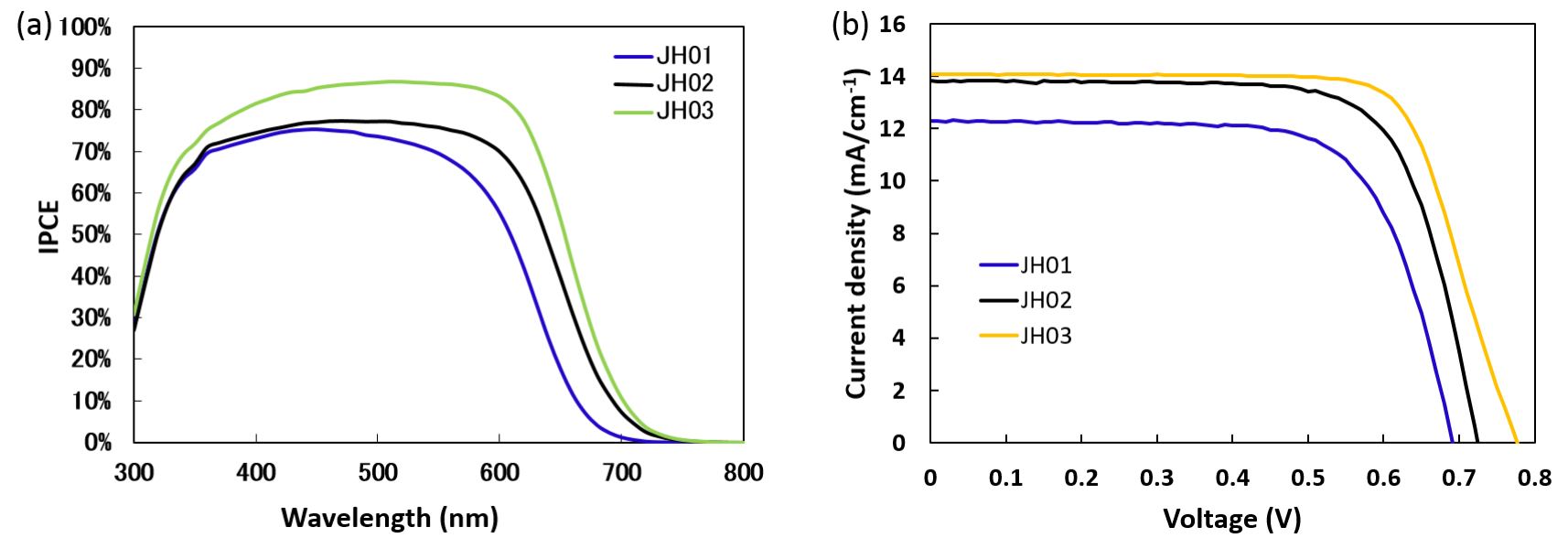

Fig. 3. (a) IPCEs of the nanocrystalline $\mathrm{TiO}_{2}$ films sensitized by $\mathrm{JH}-$ dyes. (b) I-V characteristics of $\mathrm{JH}-$ dyes.

Table 2. DSC performances of JH-dyes

\begin{tabular}{ccccc}
\hline Dye & $J_{\text {sc }}\left[\mathrm{mA} \mathrm{cm}^{-1}\right]$ & $V_{\text {oc }}[\mathrm{V}]$ & $F F$ & $\eta[\%]$ \\
\hline JH01 & 12.30 & 0.691 & 0.701 & 5.96 \\
JH02 & 13.85 & 0.724 & 0.723 & 7.25 \\
JH03 & 14.08 & 0.777 & 0.735 & 8.04 \\
\hline
\end{tabular}

The photovoltaic parameters for the DSCs based on the JH-dyes are summarized in Table 2, and the plotted current-voltage curves are shown in Fig. 3b. In accordance with the IPCE spectra, the short circuit current densities $\left(J_{\mathrm{sc}}\right)$ of the three dyes are in the order of JH01 $\left(12.30 \mathrm{~mA} \mathrm{~cm}{ }^{-2}\right)<\mathbf{J H 0 2}(13.85$ $\left.\mathrm{mA} \mathrm{cm}{ }^{-2}\right)<\mathbf{J H 0 3}\left(14.08 \mathrm{~mA} \mathrm{~cm}^{-2}\right)$. The introduction of the additional diphenylamine donor in JH02 and the use of the hexyl-substituted terthiophene $\pi$-bridge in $\mathbf{J H 0 3}$ greatly increase the $J_{\text {sc }}$. Similarly, the improved open circuit voltages $\left(V_{\mathrm{oc}}\right)$ and fill factors (FF) were also achieved for JH02 and JH03 cells. The relatively low $V_{\text {oc }}$ of $0.691 \mathrm{~V}$ for $\mathbf{J H 0 1}$ may be caused by the serious charge recombination because of the high molecular planarity of the backbone. In contrast, the presence of the nonplanar triphenylamine group in JH02 and bulky hexyl chains on the terthiophene of JH03 may sufficiently reduce the charge recombination of the electrons in the $\mathrm{TiO}_{2}$ conduction band with the electrode, resulted in higher $V_{\text {oc }}$ of $0.724 \mathrm{~V}$ for $\mathbf{J H 0 2}$ and $0.777 \mathrm{~V}$ for $\mathbf{J H 0 3}$, respectively. As a result, the $\mathbf{J H 0 3}$ cell with a FF of 0.735 exhibits the highest power conversion efficiency $(\eta)$ of $8.04 \%$.

In order to understand the $V_{\text {oc }}$ difference for JH-DSCs, we measured the relative conduction band position $\left(E_{\mathrm{CB}}\right)$ of $\mathrm{TiO}_{2}$ by means of charge extraction method (CEM) ${ }^{14}$ as shown in Fig. 4a. The $E_{\mathrm{CB}}$ measurement of all $\mathrm{JH}$-devices with the CEM shows that the $V_{\text {oc }}$ increases linearly with the logarithm of the electron density and the plots for the three dyes almost overlapped, indicating the same conduction 
band position of JH-cells. Since the conduction band edge was not affected by the different substituents in the $\mathrm{JH}$-dyes, we measured the electron life time $(\tau)$ by means of intensity-modulated photovoltage spectroscopy (IMPS) ${ }^{15}$ to understand the charge recombination. Fig. $4 \mathrm{~b}$ shows the relationship between $\tau$ and electron density for JH-cells. At a fixed voltage, the $\tau$ values of JH-cells are in the order of JH03 > JH02 > JH01, which suggest that the JH03 dye bearing hexyl chains on the $\pi$-bridge more sufficiently suppresses the charge recombination between electrons on the $\mathrm{TiO}_{2}$ surface and $\mathrm{I}_{3}{ }^{-}$ions in the electrolyte, compared to the $\mathbf{J H 0 1}$ and $\mathbf{J H 0 2}$ dyes having a higher molecular planarity.
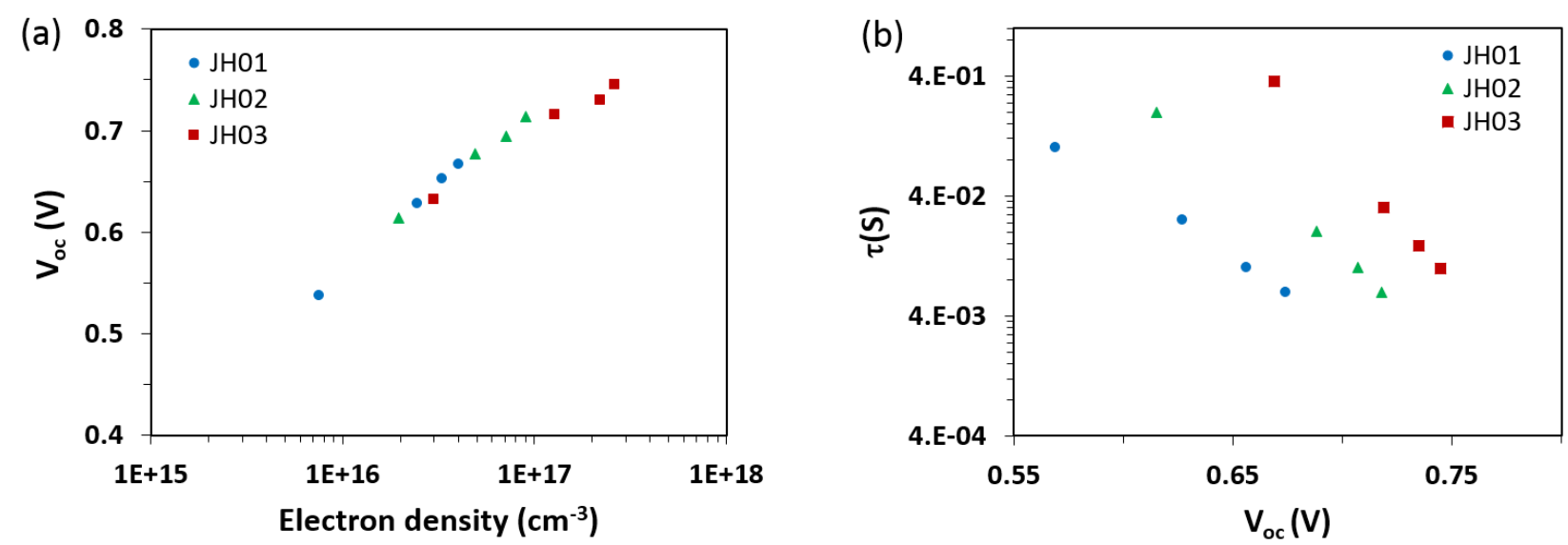

Fig. 4. (a) $V_{\text {oc }}$ as a function of electron density measured by a charge extraction method. (b) life time $(\tau)$ of electron versus electron density measured by intensity-modulated photovoltage spectroscopy.

We also performed electrochemical impedance spectra (EIS) to study the influence of electron combination and interfacial charge transfer processes on $V_{\text {oc. }}{ }^{16}$ As shown in Fig. 5a, among the three semicircles in the Nyquist plots of the JH-cells, the second semicircle in the middle-frequency range represents the electron transfer resistance $\left(R_{\mathrm{CT}}\right)$ at the $\mathrm{TiO}_{2} /$ dye/electrolyte interface. The $R_{\mathrm{CT}}$ of the JH03 cell is much larger than that of JH01 and JH02 cells, indicating that the hexyl chains of the JH03 dye shows an enhanced blocking effect to prevent the contact between the $\mathrm{TiO}_{2}$ electrode and the $\mathrm{I}_{3}{ }^{-}$in the electrolyte. In the Bode phase plot as shown in Fig. 5b, the middle-frequency response in the range of $1-100 \mathrm{~Hz}$ represents the charge recombination rate between electrolyte and $\mathrm{TiO}_{2}$. The injected electron life time in $\mathrm{TiO}_{2}$ can be determined by this middle-frequency, which is correlated to $V_{\text {oc. }}$ The middle-frequency peak of the $\mathbf{J H 0 3}$ cell shifts to the lower frequency compared to that of JH01 and JH02 cells, indicating the longer electron life time of $\mathbf{J H 0 3}$ in $\mathrm{TiO}_{2}$. This result is well-matched with the fact that $\mathbf{J H 0 3}$ possess a higher $V_{\text {oc }}$ of $0.777 \mathrm{~V}$ than that of JH01 and JH02. Overall, the JH03 dye with thieno[3,2-a]carbazle as a donor and the hexyl-substituted terthiophene as a $\pi$-bridge not only increases the charge generation and injection, but also prolong the electron life time, leading to the improvement of both $V_{\mathrm{oc}}$ and $J_{\mathrm{sc}}$, and ultimately a high conversion efficiency of $8.04 \%$. 

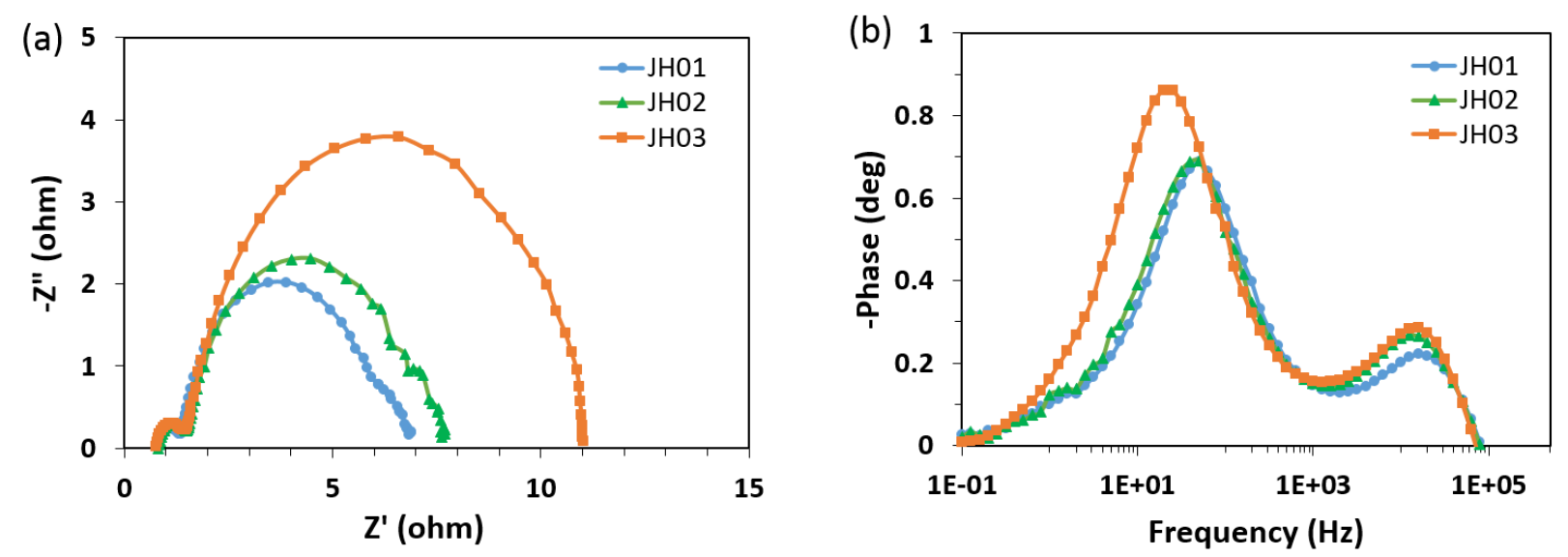

Fig. 5. (a) The EIS Nyquist plots and (b) The EIS Bode phase plots for DSCs based on JH-dyes.

\section{Conclusion}

In conclusion, we have synthesized three new D- $\pi$-A organic dyes, JH01, JH02, and JH03, using thieno[3,2-a]carbazole as a new donor unit, oligothiophene as a $\pi$-bridge, and cycanoacrylic acid an acceptor unit. The JH-dyes show strong ICT absorption bands both in solution and on $\mathrm{TiO}_{2}$. The JH01 and JH02 dyes having a bithiophene $\pi$-bridge exhibit a planar $\pi$-conjugated backbone, leading to redshifted absorption in solution and increased $\varepsilon$ values. The twisted molecule of JH03 having hexyl chains on the terthiophene $\pi$-bridge shows a red-shifted absorption on $\mathrm{TiO}_{2}$ and a highest IPCE plateau of $86 \%$ over the most of the visible region. As a result, the DSCs based on the JH03 sensitizer showed a highest $\eta$ of $8.04 \%$ with high $V_{\mathrm{oc}}$ and $J_{\mathrm{sc}}$, which is higher than that of JH01 (5.96\%) and JH02 (7.25\%). EIS and IMPS measurements clearly indicate that the higher $\eta$ of $\mathbf{J H 0 3}$ cell is mainly ascribed to the enhanced charge recombination resistance and the prolonged life time. Further design and synthesis of new [3,2a] carbazole-based organic dyes for enhancement of the light harvesting ability across a wider range of the solar spectrum are in progress.

\section{Experimental section}

\subsection{General information}

${ }^{1} \mathrm{H}$ NMR and ${ }^{13} \mathrm{C}$ NMR spectra were recorded on JEOL JMTC-270/54/SS (JASTEC, $400 \mathrm{MHz}$ ) and (JASTEC (700 MHz) spectrometers. ${ }^{1} \mathrm{H}$ NMR spectra are reported as follows: chemical shift in ppm $(\delta)$ relative to the chemical shifts of $\mathrm{CDCl}_{3}$ at $7.26 \mathrm{ppm}$ and THF- $d_{8}$ at $3.58 \mathrm{ppm}$, respectively. ${ }^{13} \mathrm{C} \mathrm{NMR}$ spectra reported in ppm $(\delta)$ relative to the central line for $\mathrm{CDCl}_{3}$ at $77 \mathrm{ppm}$ and THF- $d_{8}$ at $66.5 \mathrm{ppm}$, respectively. High-resolution mass spectra were obtained on a BRUKER APEXIII spectrometer. Cyclic voltammetry experiments were performed using a Multichannel Potentiostat (Model 1470E) from Solartron Analytical. All CV measurements were recorded in $\mathrm{CH}_{2} \mathrm{Cl}_{2}$ with $0.1 \mathrm{M}$ tetrabutylammonium hexafluorophosphate as a supporting electrolyte (scan rate of $50 \mathrm{mV} \cdot \mathrm{s}^{-1}$ ). The experiments were performed at room temperature with a conventional three electrodes configuration consisting of a platinum wire working electrode, a glassy carbon electrode, and SCE as a reference electrode. The redox and oxidation potential were determined as the midpoints between peak potential for the forward and 
reverse scan. The ionization potential (IP) of dyes bound to the nanocrystalline $\mathrm{TiO}_{2}$ film was measured using the photoelectron spectrometer surface analyser (Riken Keiki, AC-3E). Optimized ground state geometry of the lowest-energy conformer of JH-dyes were calculated at the B3LYP/6-31++(d,p) level of theory using the GAUSSIAN 09 program package. Column chromatography was carried out employing Silica gel 60N (spherical, neutral, 40 100 $\mu \mathrm{m}$, KANTO Chemical Co.). All the used anhydrous solvents and chemicals were purchased and used as received. The unprotected thieno[3,2- $a$ ] carbazole moieties 1a-c, ${ }^{10}$ and intermediates $\mathbf{4}$ and $\mathbf{5}$ were prepared according to the reported methods. ${ }^{17}$ The structure of products were determined by ${ }^{1} \mathrm{H}-\mathrm{NMR},{ }^{13} \mathrm{C}-\mathrm{NMR}$, and high resolution mass.

\subsection{Synthesis of JH-dyes}

4.2.1. 5'-(10-Octyl-5-phenyl-10H-thieno[3,2-a]carbazol-2-yl)-[2,2'-bithiophene]-5-carbaldehyde (3a): To a THF (10 mL) solution of 10-octyl-5-phenyl-10H-thieno[3,2-a]carbazole 1a (265 mg, $0.64 \mathrm{mmol})$ was added $n$ - $\mathrm{BuLi}\left(0.49 \mathrm{~mL}, 0.773 \mathrm{mmol}, 1.58 \mathrm{M}\right.$ in hexane) at $-78{ }^{\circ} \mathrm{C}$. The reaction mixture was stirred for $30 \mathrm{~min}$ at $-78{ }^{\circ} \mathrm{C}$ and then 2-isopropoxy-4,4,5,5-tetramethyl-1,3,2-dioxabororane (156 $\mu \mathrm{L}, 0.773$ mmol) was added. The reaction mixture was warmed to room temperature and stirred for $12 \mathrm{~h}$. The reaction was quenched with saturated $\mathrm{NH}_{4} \mathrm{Cl}$ aqueous solution and extracted with $\mathrm{Et}_{2} \mathrm{O}$ for 3 times. The combined organic layer was dried with anhydrous $\mathrm{Na}_{2} \mathrm{SO}_{4}$. After concentration, the yellow residue of boronate 2a was directly used to the next step without further purification.

To the mixture of 2a, 5'-bromo-[2,2'-bithiophene]-5-carbaldehyde (184 mg, $0.672 \mathrm{mmol}$ ), and $\mathrm{Pd}\left(\mathrm{PPh}_{3}\right)_{4}$ (78 mg, $0.0672 \mathrm{mmol}$ ) in diemethoxyethane $(10 \mathrm{~mL})$, was added $\mathrm{K}_{2} \mathrm{CO}_{3}(140 \mathrm{mg}, 1.008 \mathrm{mmol})$ in $\mathrm{H}_{2} \mathrm{O}$ $(1 \mathrm{~mL})$. The reaction mixture was refluxed under an argon atmosphere for $12 \mathrm{~h}$. After adding brine, the reaction was extracted with ethyl acetate for 3 times. The combined organic layer was washed with water and dried with anhydrous $\mathrm{Na}_{2} \mathrm{SO}_{4}$. After concentration, the residue was purified by silica gel chromatography using hexane/ $\mathrm{CH}_{2} \mathrm{Cl}_{2}(1: 1)$ as eluents to give the corresponding aldehyde $\mathbf{3 a}$ (314 $\mathrm{mg}, 2$ steps: $81 \%$ ) as a red solid. ${ }^{1} \mathrm{H}$ NMR $\left(400 \mathrm{MHz} \mathrm{CDCl}_{3}\right) \delta 9.85(\mathrm{~s}, 1 \mathrm{H}), 7.89(\mathrm{~s}, 1 \mathrm{H}), 7.66-7.62(\mathrm{~m}, 3 \mathrm{H})$, $7.57-7.51(\mathrm{~m}, 3 \mathrm{H}), 7.48-7.46(\mathrm{~m}, 2 \mathrm{H}), 7.41(\mathrm{t}, J=7.8 \mathrm{~Hz}, 1 \mathrm{H}), 7.35(\mathrm{~d}, J=8.0 \mathrm{~Hz}, 1 \mathrm{H}), 7.30(\mathrm{~d}, J=3.6$ $\mathrm{Hz}, 1 \mathrm{H}), 7.25(\mathrm{~d}, J=7.6 \mathrm{~Hz}, 1 \mathrm{H}), 7.24(\mathrm{~d}, J=7.6 \mathrm{~Hz}, 1 \mathrm{H}), 7.01(\mathrm{t}, J=7.6 \mathrm{~Hz}, 1 \mathrm{H}), 4.63(\mathrm{t}, J=7.6 \mathrm{~Hz}$, 2H), 2.07-1.99 (m, 2H), 1.63-1.55 (m, 2H), 1.51-1.44 (m, 2H), 1.38-1.31 (m, 6H), $0.88(\mathrm{t}, J=7.2 \mathrm{~Hz}$, $3 \mathrm{H}) ;{ }^{13} \mathrm{C}$ NMR $\left(100 \mathrm{MHz}, \mathrm{CDCl}_{3}\right)$ one aromatic peak is not shown due to accidental degeneracy; $\delta$ $182.19,146.35,141.61,140.88,139.59$, 139.17, 138.60, 137.15, 135.76, 134.96, 134.58, 129.22, 128.36, $127.62,126.89,125.46,124.71,124.02,123.42,122.52,121.92,119.03,117.27,117.16,114.44,108.60$, 44.82, 31.91, 29.69, 29.54, 29.45, 27.32, 22.73, 14.16. HRMS $\left(\mathrm{ESI}^{+}\right): \mathrm{m} / z$ : calcd for $\mathrm{C}_{37} \mathrm{H}_{33} \mathrm{NOS}_{3}$ : $\left[\mathrm{M}+\mathrm{H}^{+}\right], 604.1797$; found: 604.1797.

4.2.2. 2-Cyano-3-(5'-(10-octyl-5-phenyl-10H-thieno[3,2-a]carbazol-2-yl)-[2,2'-bithiophen]-5-yl)acrylic acid (JHO1): A mixture of 3a (120 mg, $0.2 \mathrm{mmol}), \mathrm{CNCH}_{2} \mathrm{COOH}$ (51 mg, $0.6 \mathrm{mmol}$ ), and $\mathrm{AcONH}_{4}$ $(15.4 \mathrm{mg}, 0.2 \mathrm{mmol})$ in acetic acid $(2 \mathrm{~mL})$ was heated to reflux for $12 \mathrm{~h}$. After cooling to room temperature, the solvent was removed under the reduced pressure and the residue was directly purified 
by silica gel chromatography $\left(\mathrm{CHCl}_{3}: \mathrm{EtOH}=10: 1\right)$ to yield $\mathbf{J H 0 1}$ as a dark red solid as the final product (88 mg, 66\%). ${ }^{1} \mathrm{H}$ NMR (400 MHz, $\left.\mathrm{C}_{4} \mathrm{D}_{8} \mathrm{O}\right) \delta 8.37(\mathrm{~s}, 1 \mathrm{H}), 8.15(\mathrm{~s}, 1 \mathrm{H}), 7.84(\mathrm{~d}, J=4.0 \mathrm{~Hz}, 1 \mathrm{H}), 7.62-$ $7.59(\mathrm{~m}, 3 \mathrm{H}), 7.57(\mathrm{~d}, J=4 \mathrm{~Hz}, 1 \mathrm{H}), 7.55-7.50(\mathrm{~m}, 4 \mathrm{H}), 7.48-7.46(\mathrm{~m}, 2 \mathrm{H}), 7.35(\mathrm{t}, J=7.6 \mathrm{~Hz}, 1 \mathrm{H})$, $7.31(\mathrm{~d}, J=7.6 \mathrm{~Hz}, 1 \mathrm{H}), 6.92(\mathrm{t}, J=7.6 \mathrm{~Hz}, 1 \mathrm{H}), 4.82(\mathrm{t}, J=7.6 \mathrm{~Hz}, 2 \mathrm{H}), 2.08-2.00(\mathrm{~m}, 2 \mathrm{H}), 1.73-1.57$ $(\mathrm{m}, 2 \mathrm{H}), 1.56-1.45(\mathrm{~m}, 2 \mathrm{H}), 1.43-1.29(\mathrm{~m}, 6 \mathrm{H}), 0.86(\mathrm{t}, J=7.2 \mathrm{~Hz}, 3 \mathrm{H}) ;{ }^{13} \mathrm{C} \mathrm{NMR}\left(100 \mathrm{MHz}, \mathrm{C}_{4} \mathrm{D}_{8} \mathrm{O}\right) \delta$ $162.89,145.60,145.31,141.28,139.98,139.24,139.15,138.64,135.93,135.14,134.95,134.63,134.56$, 129.16, 128.21, 127.46, 127.32, 125.91, 124.54, 124.38, 123.68, 122.55, 121.66, 118.79, 117.49, 117.39, 115.63, 114.33, 108.84, 98.97, 44.33, 31.97, 29.78, 29.63, 29.48, 27.20, 22.69, 13.60. HRMS (ESI $\left.{ }^{+}\right)$: $m / z$ : calcd for $\mathrm{C}_{40} \mathrm{H}_{34} \mathrm{~N}_{2} \mathrm{O}_{2} \mathrm{~S}_{3}$ : [M-H'], 669.1710; found: 669.1709 .

4.2.3. 4-(10-Octyl-10H-thieno[3,2-a]carbazol-5-yl)-N,N-diphenylaniline (1 $\left.\boldsymbol{b}^{\prime}\right)$ : To a solution of 5-(4bromophenyl)-10H-thieno[3,2-a]carbazole (1b) $(224 \mathrm{mg}, 0.46 \mathrm{mmol}), \mathrm{HNPh}_{2}$ (93 $\mathrm{mg}, 0.55 \mathrm{mmol}$ ), $\mathrm{Pd}_{2}(\mathrm{dba})_{3}(4.2 \mathrm{mg}, 0.0046 \mathrm{mmol})$, and $\mathrm{NaO}^{t} \mathrm{Bu}(53 \mathrm{mg}, 0.552 \mathrm{mmol})$ in toluene $(10 \mathrm{~mL})$ was added $(t-$ $\mathrm{Bu})_{3} \mathrm{P}(4.3 \mu \mathrm{L}, 0.02 \mathrm{mmol})$ at room temperature under an argon atmosphere. The reaction mixture was heated at $100{ }^{\circ} \mathrm{C}$ for $1 \mathrm{~h}$. After cooling to room temperature, the solvent was removed and the residue was directly purified by silica gel chromatography using hexane $/ \mathrm{CH}_{2} \mathrm{Cl}_{2}(1: 1)$ as eluents to give the corresponding product $\mathbf{1 b}^{\prime}(201 \mathrm{mg}, 75 \%)$ as a yellow solid. ${ }^{1} \mathrm{H} \mathrm{NMR}\left(400 \mathrm{MHz}, \mathrm{CDCl}_{3}\right) \delta 7.87(\mathrm{~d}, J=$ $5.6 \mathrm{~Hz}, 1 \mathrm{H}), 7.66(\mathrm{~s}, 1 \mathrm{H}), 7.63(\mathrm{~d}, J=8.0 \mathrm{~Hz}, 1 \mathrm{H}), 7.58-7.52(\mathrm{~m}, 4 \mathrm{H}), 7.46(\mathrm{t}, J=7.2 \mathrm{~Hz}, 1 \mathrm{H}), 7.37-$ 7.33 (m, 4H), 7.30-7.27 (m, 6H), 7.14-7.08 (m, 3H), 4.68 (t, J=7.6 Hz, 2H), 2.08-2.00 (m, 2H), 1.61$1.53(\mathrm{~m}, 2 \mathrm{H}), 1.43-1.33(\mathrm{~m}, 8 \mathrm{H}), 0.93(\mathrm{t}, J=7.2 \mathrm{~Hz}, 3 \mathrm{H}) ;{ }^{13} \mathrm{C}$ NMR $\left(100 \mathrm{MHz}, \mathrm{CDCl}_{3}\right) \delta 147.70$, $147.15,139.56,139.29,135.23,134.94,134.60,130.17,129.22,124.91,124.77,124.37,123.44,122.90$, $122.81,122.71,121.92,120.25,118.75,116.72,114.79,108.58,44.84,31.83,29.94,29.48,29.24$, 27.25, 22.68, 14.16. HRMS (ESI $\left.{ }^{+}\right): m / z$ : calcd for $\mathrm{C}_{40} \mathrm{H}_{38} \mathrm{~N}_{2} \mathrm{~S}$ : [M+H $\left.{ }^{+}\right], 579.2829$; found: 579.2828 .

4.2.4. 5'-(5-(4-(Diphenylamino)phenyl)-10-octyl-10H-thieno[3,2-a]carbazol-2-yl)-[2,2'-bithiophene]-5carbaldehyde $(\mathbf{3 b})$ : The procedure is similar to the synthesis of compound $\mathbf{3 c}$; red solid; $81 \%$ yield. ${ }^{1} \mathrm{H}$ NMR (400 MHz, $\left.\mathrm{CDCl}_{3}\right) \delta 9.88(\mathrm{~s}, 1 \mathrm{H}), 7.90(\mathrm{~s}, 1 \mathrm{H}), 7.68(\mathrm{~d}, J=4.0 \mathrm{~Hz}, 1 \mathrm{H}), 7.62(\mathrm{~d}, J=8.0 \mathrm{~Hz}, 1 \mathrm{H})$, 7.54-7.44 (m, 5H), 7.37-7.32 (m, 5H), 7.29-7.25 (m, 8H), 7.13-7.08 (m, 3H), $4.65(\mathrm{t}, J=7.6 \mathrm{~Hz}, 2 \mathrm{H})$, 2.09-2.02 (m, 2H), 1.65-1.58 (m, 2H), 1.54-1.47 (m, 2H), 1.41-1.34 (m, 6H), $0.91(\mathrm{t}, J=6.8 \mathrm{~Hz}, 3 \mathrm{H})$; ${ }^{13} \mathrm{C}$ NMR $\left(100 \mathrm{MHz}, \mathrm{CDCl}_{3}\right) \delta 181.98,147.57,147.23,146.13,141.38,139.47,139.03,138.56,136.97$, $135.38,134.69,134.50,134.29,130.00,129.22,126.69,125.19,125.00,124.60,124.39,123.78,123.21$, $123.16,122.88,122.50,121.90,118.92,117.15,116.97,114.31,108.51,44.61,31.88,29.53,29.48$, 29.45, 27.25, 22.70, 14.15. HRMS $\left(\mathrm{ESI}^{+}\right): \mathrm{m} / z$ : calcd for $\mathrm{C}_{49} \mathrm{H}_{42} \mathrm{~N}_{2} \mathrm{OS}_{3}$ : $\left[\mathrm{M}+\mathrm{H}^{+}\right], 771.2532$; found: 771.2532 .

4.2.5. 2-Cyano-3-(5'-(5-(4-(diphenylamino)phenyl)-10-octyl-10H-thieno[3,2-a]carbazol-2-yl)-[2,2'bithiophen]-5-yl)acrylic acid (JH02): To a solution of $\mathbf{3 b}$ (100 $\mathrm{mg}, 0.13 \mathrm{mmol})$ and cyanoacetic acid (33 $\mathrm{mg}, 0.39 \mathrm{mmol})$ in $1.5 \mathrm{~mL}$ of chloroform was added piperidine $(90 \mu \mathrm{L}, 0.91 \mathrm{mmol})$. The reaction mixture then refluxed for $12 \mathrm{~h}$. After removal of the solvent, the residue was purified by column 
chromatography ( ilica gel, $\mathrm{CHCl}_{3}: \mathrm{EtOH}=10: 1 \mathrm{v} / \mathrm{v}$ ) to give a dark red solid $(65 \mathrm{mg}, 60 \%) .{ }^{1} \mathrm{H} \mathrm{NMR}$ $\left(400 \mathrm{MHz}, \mathrm{C}_{4} \mathrm{D}_{8} \mathrm{O}\right) \delta 8.36(\mathrm{~s}, 1 \mathrm{H}), 8.13(\mathrm{~s}, 1 \mathrm{H}), 7.82(\mathrm{~d}, J=3.6 \mathrm{~Hz}, 1 \mathrm{H}), 7.60(\mathrm{t}, J=7.2 \mathrm{~Hz}, 2 \mathrm{H}), 7.56-$ $7.50(\mathrm{~m}, 4 \mathrm{H}), 7.46-7.43(\mathrm{~m}, 2 \mathrm{H}), 7.37(\mathrm{t}, J=7.6 \mathrm{~Hz}, 1 \mathrm{H}), 7.30(\mathrm{t}, J=7.6 \mathrm{~Hz}, 4 \mathrm{H}), 7.23-7.18(\mathrm{~m}, 6 \mathrm{H})$, 7.05-6.99 (m, 3H), $4.80(\mathrm{t}, J=7.2 \mathrm{~Hz}, 2 \mathrm{H}), 2.07-1.99(\mathrm{~m}, 2 \mathrm{H}), 1.63-1.56(\mathrm{~m}, 2 \mathrm{H}), 1.50-1.43(\mathrm{~m}, 2 \mathrm{H})$, $1.38-1.31(\mathrm{~m}, 6 \mathrm{H}), 0.86(\mathrm{t}, J=7.2 \mathrm{~Hz}, 3 \mathrm{H}) ;{ }^{13} \mathrm{C} \mathrm{NMR}\left(100 \mathrm{MHz}, \mathrm{C}_{4} \mathrm{D}_{8} \mathrm{O}\right) \delta 162.91,147.85,147.53$, $145.61,145.31,139.96,139.27,139.19,138.71,135.65,135.18,135.06,134.91,134.70,134.40,130.06$, $129.18,127.32,125.85,124.51,124.41,124.34,123.53,123.18,122.88,122.60,121.80,118.82,117.49$, 117.39, 115.66, 114.36, 108.84, 98.92, 44.33, 31.98, 29.78, 29.64, 29.50, 27.22, 22.71, 13.62. HRMS $\left(\mathrm{ESI}^{+}\right)$: $m / z$ : calcd for $\mathrm{C}_{52} \mathrm{H}_{43} \mathrm{~N}_{3} \mathrm{O}_{2} \mathrm{~S}_{3}:\left[\mathrm{M}-\mathrm{H}^{+}\right], 836.2445$; found: 836.2445.

4.2.6. 5"-(10-Ethyl-5-phenyl-10H-thieno[3,2-a]carbazol-2-yl)-3,4',4"-trihexyl-[2,2':5',2"-terthiophene]5-carbaldehyde $(\mathbf{3} \boldsymbol{c})$ : The procedure is similar to the synthesis of compound $\mathbf{3 a}$ and $\mathbf{3 b}$; red solid, $80 \%$ yield. ${ }^{1} \mathrm{H}$ NMR $\left(400 \mathrm{MHz}, \mathrm{CDCl}_{3}\right) \delta 9.83(\mathrm{~s}, 1 \mathrm{H}), 7.91(\mathrm{~s}, 1 \mathrm{H}), 7.66-7.64(\mathrm{~d}, J=8.0 \mathrm{~Hz}, 2 \mathrm{H}), 7.60$ (s, $1 \mathrm{H}), 7.58-7.50(\mathrm{~m}, 5 \mathrm{H}), 7.43(\mathrm{t}, J=7.6 \mathrm{~Hz}, 1 \mathrm{H}), 7.37(\mathrm{~d}, J=8.4 \mathrm{~Hz}, 1 \mathrm{H}), 7.16(\mathrm{~s}, 1 \mathrm{H}), 7.09(\mathrm{~s}, 1 \mathrm{H})$, $7.02(\mathrm{t}, J=7.6 \mathrm{~Hz}, 1 \mathrm{H}), 4.78(\mathrm{q}, J=7.2 \mathrm{~Hz}, 2 \mathrm{H}), 2.93(\mathrm{t}, J=7.6 \mathrm{~Hz}, 2 \mathrm{H}), 2.85(\mathrm{t}, J=7.6 \mathrm{~Hz}, 4 \mathrm{H}), 1.82-$ $1.68(\mathrm{~m}, 6 \mathrm{H}), 1.65(\mathrm{t}, J=7.2 \mathrm{~Hz}, 3 \mathrm{H}), 1.48-1.35(\mathrm{~m}, 18 \mathrm{H}), 0.94-0.88(\mathrm{~m}, 9 \mathrm{H}) ;{ }^{13} \mathrm{C}$ NMR $(100 \mathrm{MHz}$, $\left.\mathrm{CDCl}_{3}\right) \delta 182.26,141.02,140.96,140.80,140.25,140.13,139.91,139.14,139.09,138.93,135.21$, $134.39,134.34,133.99,132.60,132.55,131.27,130.32,129.24,129.12,128.31,127.51,124.61,123.24$, 122.74, 121.94, 118.99, 118.63, 117.10, 114.32, 108.27, 39.47, 31.77, 31.68, 31.64, 31.61, 30.84, 30.51, $30.23,29.66,29.47,29.44,29.43,29.28,29.19,22.71,22.69,22.65,14.82,14.16$, one aliphatic peak is not shown due to accidental degeneracy. HRMS $\left(\mathrm{ESI}^{+}\right)$: $\mathrm{m} / z$ : calcd for $\mathrm{C}_{53} \mathrm{H}_{59} \mathrm{NOS}_{4}$ : $\left[\mathrm{M}+\mathrm{H}^{+}\right], 854.3552$; found: 854.3552 .

4.2.7. 2-cyano-3-(5"-(10-ethyl-5-phenyl-10H-thieno[3,2-a]carbazol-2-yl)-3,4',4"-trihexyl-[2,2':5',2"terthiophen]-5-yl)acrylic acid (JH03): The procedure is similar to the synthesis of compound JH01 and JH02; dark red solid, 89\% yield. ${ }^{1} \mathrm{H}$ NMR $\left(400 \mathrm{MHz}, \mathrm{C}_{4} \mathrm{D}_{8} \mathrm{O}\right) \delta 8.30(\mathrm{~s}, 1 \mathrm{H}), 8.04(\mathrm{~s}, 1 \mathrm{H}), 7.74(\mathrm{~s}, 1 \mathrm{H})$, 7.63-7.59 (m, 3H), 7.55-7.46 (m, 4H), 7.37-7.31 (m, 3H), $7.22(\mathrm{~s}, 1 \mathrm{H}), 6.92(\mathrm{t}, J=7.2 \mathrm{~Hz}, 1 \mathrm{H}), 4.86(\mathrm{q}$, $J=7.2 \mathrm{~Hz}, 2 \mathrm{H}), 2.98(\mathrm{t}, J=7.6 \mathrm{~Hz}, 2 \mathrm{H}), 2.90(\mathrm{t}, J=7.6 \mathrm{~Hz}, 4 \mathrm{H}), 1.85-1.72(\mathrm{~m}, 6 \mathrm{H}), 1.61(\mathrm{t}, J=7.2 \mathrm{~Hz}$, $3 \mathrm{H}), 1.48-1.37(\mathrm{~m}, 18 \mathrm{H}), 0.94-0.88(\mathrm{~m}, 9 \mathrm{H}) ;{ }^{13} \mathrm{C} \mathrm{NMR}\left(100 \mathrm{MHz}, \mathrm{C}_{4} \mathrm{D}_{8} \mathrm{O}\right) \delta 162.95,145.28,141.41$, $141.14,141.05,140.67,140.21,140.14,139.42,139.18,135.46,134.38,134.04,133.47,132.66,132.63$, 131.46, 130.69, 129.39, 129.19, 128.21, 127.41, 124.51, 123.42, 122.72, 121.69, 119.15, 118.77, 117.21, $115.55,114.16,108.47,98.97,39.15,31.88,31.78,30.90,30.62,30.14,29.53,29.49,29.39$, 29.34, $29.24,29.15,22.74,22.69,14.23,13.65,13.62$ one aliphatic peak is not shown due to accidental degeneracy. HRMS (ESI ${ }^{+}$): $m / z$ : calcd for $\mathrm{C}_{56} \mathrm{H}_{60} \mathrm{~N}_{2} \mathrm{O}_{2} \mathrm{~S}_{4}$ : [M-H ${ }^{+}$, 919.3465; found: 919.3464 .

\subsection{Fabrication of the DSCs}

A double-layer $\mathrm{TiO}_{2}$ photoelectrode $(10+5) \mu \mathrm{m}$ in thickness with a $10 \mu \mathrm{m}$ thick nanoporous layer and a $5 \mu \mathrm{m}$ thick scattering layer (area: $0.25 \mathrm{~cm}^{2}$ ) was prepared by screen printing on conducting glass substrate. A dye solution of JH-dyes with $3 \times 10^{-4} \mathrm{M}$ concentration in acetonitrile/tert-butyl alcohol (1/1, 
v/v) was used to up take the dye on to the $\mathrm{TiO}_{2}$ film. Deoxycholic acid (DCA) $(20 \mathrm{mM})$ as a coadsorbent was added into the dye solution to prevent aggregation of the dye molecules. $\mathrm{The}^{\mathrm{TiO}} \mathrm{f}_{2}$ films were immersed into the dye solution and then kept at $25{ }^{\circ} \mathrm{C}$ for $30 \mathrm{~h}$. Photovoltaic measurements were performed in a sandwich type solar cell in conjunction with an electrolyte consisting of a solution of 0.6 $\mathrm{M}$ dimethylpropyl-imidazolium iodide (DMPII), $0.05 \mathrm{M} \mathrm{I}_{2}, 0.1 \mathrm{M} \mathrm{LiI}$ and $0.5 \mathrm{M}$ tert-butylpyridine (TBP) in acetonitrile (AN). The dye-deposited $\mathrm{TiO}_{2}$ film and a platinum-coated conducting glass were separated by a Surlyn spacer ( $40 \mu \mathrm{m}$ thick) and sealed by heating the polymer frame. Photocurrent density-voltage (I-V) of sealed solar cells was measured under AM $1.5 \mathrm{G}$ simulated solar light at a light intensity of $100 \mathrm{~mW} \mathrm{~cm}{ }^{-2}$ with a metal mask of $0.25 \mathrm{~cm}^{2}$. The photovoltaic parameters, i.e. short circuit current $\left(J_{\mathrm{sc}}\right)$, open circuit voltage $\left(V_{\mathrm{oc}}\right)$, fill factor $(\mathrm{FF})$, and power conversion efficiency $(\eta)$ were estimated from I-V characteristics under illumination. The photoemission yield curves were measured with a Riken Keiki Co. Ltd. model AC-3E photoelectron spectrometer surface analyser under atmosphere with a $0.2 \mathrm{~mL} \mathrm{~min}^{-1} \mathrm{~N}_{2}$ flow.

\subsection{Electrochemical impedance spectroscopy (EIS) and intensity-modulated photovoltage spectroscopy (IMVS) measurements}

The IMVS spectra were measured with a potentiostat (Solartron 1287) equipped with a frequency response analyser (Solartron 1255B) at an open-circuit condition, based on a monochromatic illumination $(420 \mathrm{~nm})$ controlled by Lab-view system, to obtain the photovoltaic response induced by the modulated light. The modulated light was driven with a $10 \%$ AC perturbation current superimposed on a DC current in a frequency range from 0.1 to $10^{6} \mathrm{~Hz}$. The charge extraction method (CEM) was performed with the same monochromatic light source. The solar cell was illuminated at an open-circuit condition for $5 \mathrm{~s}$ to attain a steady state and then the light source was switched off when the device simultaneously switched to a short-circuit condition to extract the charges generated at that light intensity. The electrochemical impedance spectra were measured with an impedance analyser (Solartron Analytical, 1255B) connected with a potentiostat (Solartron Analytical, 1287) under illumination using a solar simulator (WXS-155S-10: Wacom Denso Co. Japan). EIS spectra were recorded over a frequency range of $10^{-2}$ to $10^{6} \mathrm{~Hz}$ at $298 \mathrm{~K}$. The applied bias voltage and AC amplitude were set at the $V_{\text {oc }}$ of the DSCs. The electrical impedance spectra were characterized using Z-View software (Solartron Analytical).

\section{Acknowledgement}

This work was supported by World Premier International Research Center Initiative (WPI), MEXT (Japan). This work was partly supported by Core Research for Evolutional Science and Technology (CREST) of the Japan Science and Technology Agency. A.I. acknowledges the support of the JSPS KAKENHI grant No. 26288113.

\section{References and notes}


1. (a) O’Regan, B.; Grätzel, M. Nature 1991, 353, 737; (b) Hagfeldt, A.; Grätzel, M. Chem. Rev. 1995, 95, 49; (c) Hagfeldt, A.; Grätzel, M. Acc. Chem. Res. 2000, 33, 269.

2. For recent selected reviews: (a) Robertson, N. Angew. Chem., Int. Ed. 2006, 45, 2338; (b) Mishra, A.; Fischer, M. K. R.; Bäuerle, P. Angew. Chem., Int. Ed. 2009, 48, 2474; (c) Hagfeldt, A.; Boschloo, G.; Sun, L. C.; Kloo, L.; Pettersson, H. Chem. Rev. 2010, 110, 6595; (d) Ning, Z. J.; Fu N.; Tian, H. Energy Environ. Sci. 2010, 3, 1170; (e) Clifford, J. N.; Martinez-Ferrero, E.; Viterisi, A.; Palomares, E. Chem. Soc. Rev. 2011, 40, 1635; (f) Chen, Y. S.; Chou, H. H.; Chen, Y. C.; Hsu, C. Y.; Lin, J. T. J. Mater. Chem. 2012, 22, 8734; (g) Liang, M.; Chen, J. Chem. Soc. Rev. 2013, 42, 3453; (h) Wu, Y.; Zhu, W. Chem. Soc. Rev. 2013, 42, 2039.

3. Zeng W.; Cao Y.; Bai Y.; Wang Y.; Shi Y.; Zhang M.; Wang F.; Pan C.; Wang, P. Chem. Mater. 2010, 22, 1915.

4. (a) Yella A.; Lee H. W.; Tsao H. N.; Yi C.; Chandiran A. K.; Nazeeruddin M. K.; Diau E. W.-G; Yeh C.-Y.; Zakeeruddin S. D.; Grätzel M. Science 2011, 334, 629; (b) Chiba, Y.; Islam, A.; Watanabe, Y.; Komiya, R.; Koide, N.; Han, L. Y. Jpn. J. Appl. Phys. 2006, 45, L638; (c) Han, L. Y.; Islam, A.; Chen, H.; Malapaka, C.; Chiranjeevi, B.; Zhang, S. F.; Yang, X. D.; Yanagida, M. Energy Environ. Sci. 2012, 5, 6057.

5. Selected examples: (a) Hara, K.; Sayama, K.; Ohga, Y.; Shinpo, A.; Suga, S.; Arakawa, H. Chem. Commun. 2001, 569; (b) Ferrere, S.; Gregg, B. A. New J. Chem. 2002, 26, 1155; (c) Hagberg, D. P.; Edvinsson, T.; Marinado, T.; Boschloo, G.; Hagfeldt, A.; Sun, L. Chem. Commun. 2006, 2245; (d) Koumura, N.; Wang, Z. S.; Mori, S.; Miyashita, M.; Suzuki, E.; Hara, K. J. Am. Chem. Soc. 2006, 128, 14256; (e) Horiuchi, T.; Miura, H.; Uchida, S. Chem. Commun. 2003, 3036.

6. (a) Kim, S.; Lee, J. K.; Kang, S. O.; Ko, J.; Yum, J. H.; Fantacci, S.; DeAngelis, F.; DiCenso, D.; Nazeeruddin, M. K.; Grätzel, M. J. Am. Chem. Soc. 2006, 128, 16701; (b) Ito, S.; Miura, H.; Uchida, S.; Takada, M.; Sumioka, K.; Liska, P.; Comte, P.; Pechy, P.; Grätzel, M. Chem. Commun. 2008, 5194; (c) Hagberg, D. P.; Yum, J.-H.; Lee, H.; De Angelis, F.; Marinado, T.; Karlsson, K. M.; Humphry-Baker, R.; Sun, L.; Hagfeldt, A.; Grätzel, M.; Nazeeruddin, M. K. J. Am. Chem. Soc. 2008, 130, 6259; (d) Zhang, G.; Bala, H.; Cheng, Y.; Shi, D.; Lv, X.; Yu, Q.; Wang, P. Chem. Commun. 2009, 2198; (e) Mao, J.; He, N.; Ning, Z.; Zhang, Q.; Guo, F.; Chen, L.; Wu, W.; Hua, J.; Tian, H. Angew. Chem., Int. Ed. 2012, 51, 9873; (f) Liu, B.; Wang, B.; Wang, R.; Gao, L.; Huo, S.; Liu, Q.; Li, X.; Zhu, W. J. Mater. Chem. A 2014, 2, 804; (g) Qu, S.; Qin, C.; Islam, A.; Wu, Y.; Zhu, W.; Hua, J.; Tian, H.; Han, L. Chem. Commun. 2009, 48, 6972.

7. (a) Li, R.; Liu, J.; Cai, N.; Zhang, M.; Wang, P. J. Phys. Chem. B 2010, 114, 4461; (b) Chen, J.-H.; Tsai, C.-H.; Wang, S.-A.; Lin, Y.-Y.; Huang, T.-W.; Chiu, S.-F.; Wu, C.-C.; Wong, K.-T. J. Org. Chem. 2011, 76, 8977; (c) Zhu, X.; Tsuji, H.; Yella, A.; Chauvin, A.; Grätzel, M.; Nakamura, E. Chem. Commun. 2013, 49, 582; (d) Liu, J.; Numata, Y.; Qin, C.; Islam, A.; Yang, X.; Han, L. Chem. Commun. 2013, 49, 7587.

8. (a) Zhao, J.; Jin, T.; Islam, A.; Kwon, E.; Akhtaruzzaman, M.; Asao, N.; Han, L.; Alamry, K. A.; Kosa, S. A.; Asiri, A. M.; Yamamoto, Y. Tetrahedron 2014, 70, 6211; (b) Zhao, J.; Oniwa, K.; Islam, A.; Qin, C.; Asao, N.; Han, L.; Yamamoto, Y.; Jin, T. Org. Chem. Front. 2015, 2, 253. 
9. (a) Akhtaruzzaman, M.; Islam, A.; Yang, F.; Asao, N.; Kwon, E.; Singh, S. P.; Han, L. Y.; Yamamoto, Y. Chem. Commun. 2011, 47, 12400; (b) Akhtaruzzaman, M.; Seya, Y.; Asao, N.; Islam, A.; Kwon, E.; El-Shafei, A.; Han, L. Y.; Yamamoto, Y. J. Mater. Chem. 2012, 22, 10771; (c) Ferrara, G.; Jin, T.; Akhtaruzzaman, M.; Islam, A.; Han, L.; Jiang, H.; Yamamoto, Y. Tetrahedron Lett. 2012, 53, 1946; (d) Yang, F.; Akhtaruzzaman, M.; Islam, A.; Jin, T.; El-Shafei, A.; Qin, C.; Han, L.; Alamry, K. A.; Kosa, S. A.; Hussien, M. K.; Asiri A. M.; Yamamoto, Y. J. Mater. Chem. 2012, 22, 22550; (e) Akhtaruzzaman, M.; Menggenbateer; Islam, A.; El-Shafei, A.; Asao, N.; Jin, T.; Han, L.; Alamry, K. A.; Kosa, S. A.; Asiri, A. M.; Yamamoto, Y. Tetrahedron 2013, 69, 3444.

10. Ferrara, G.; Jin, T.; Oniwa, K.; Zhao, J.; Asiri A. M.; Yamamoto, Y. Tetrahedron Lett. 2012, 53, 914.

11. Wolfe, J. P.; Wagaw, S.; Buchwald, S. L. J. Am. Chem. Soc. 1996, 118, 7215.

12. Kim, D.; Lee, J. K.; Kang, S. O.; Ko, J. Tetrahedron 2007, 63, 1913.

13. Oskam, G.; Bergeron, B. V.; Meyer, G. J.; Searson, P. C. J. Phys. Chem. B 2001, 105, 6867.

14. Duffy, N. W.; Peter, L. M.; Rajapakse, R. M. G.; Wijayantha, K. G. U. J. Phys. Chem. B 2000, 104, 8916.

15. Schlichthierl, G.; Huang, S. Y.; Sprague, J.; Frank, A. J. J. Phys. Chem. B 1997, 101, 8141.

16. (a) Tian, H.; Bora, I.; Jiang, X.; Gabrielsson, E.; Karlsson, K. M.; Hagfeldt, A.; Sun, L. J. Mater. Chem. 2011, 21, 12462; (b) Qin, C.; Islam, A.; Han, L. J. Mater. Chem. 2012, 22, 19236; (c) Haid, S.; Marszalek, M.; Mishra, A.; Wielopolski, M.; Teuscher, J.; Moser, J.-E.; Humphry-Baker, R.; Zakeeruddin, S. M.; Grätzel, M.; Bäuerle, P. Adv. Funct. Mater. 2012, 22, 1291.

17. (a) Melucci, M.; Barbarella, G.; Zambianchi, M.; Di Pietro, P.; Bongini, A. J. Org. Chem. 2004, 69, 4821; (b) Liu, Y.; Wan, X.; Wang, F.; Zhou, J.; Long, G.; Tian, J.; Chen, Y. Adv. Mater. 2011, 23, 5387. 


\section{Graphical Abstract}

To create your abstract, type over the instructions in the template box below.

Fonts or abstract dimensions should not be changed or altered.

Efficient thieno[3,2-a]carbazole-based

Leave this area blank for abstract info.

organic dyes for dye-sensitized solar cells

Hua Jiang, Kazuaki Oniwa, Ashraful Islam,* Jian Zhao, Liyuan Han, Ying-Ji Sun, Ming Bao, Naoki Asao, Yoshinori Yamamoto, Tienan Jin*

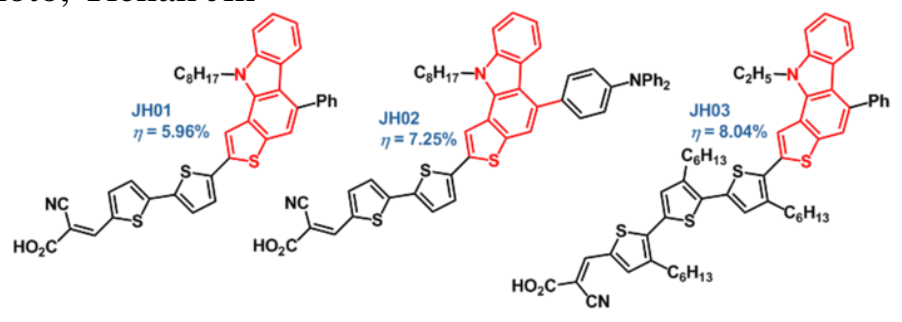

